VPLYV OCHORENIA NA ŽIVOT RODIČOV DIEŤAŤA S ASTMOU - PILOTNÁ ŠTÚDIA

\title{
INFLUENCE OF DISEASES ON LIVING PARENTS OF THE CHILD WITH ASTMA - PILOT STUDY
}

\author{
Alena Valancová, Elena Gurková \\ Ústav ošetrovatel'stva, Jesseniova lekárska fakulta v Martine, \\ Univerzita Komenského v Bratislave
}

\section{Abstrakt}

Cielom práce bolo zistit vplyv astmy bronchiale na kvalitu života rodín $s$ diet’atom $s$ daným ochorením. Prostredníctvom dotazníka merania kvality života rodín dietata $s$ astmou, Paediatric Asthma Caregiver's Quality of Life Questionnare, autori zistovali subjektívne vnímanie vplyvu ochorenia na život rodičov diet’at’a s astmou a problémové oblasti v živote, ktoré najviac znepokojujú rodičov. Vzorku tvorilo 21 rodičov, ktorých deti absolvovali rekondičný pobyt vo Vysokých Tatrách. $\mathrm{Na}$ základe analýzy získaných údajov zistili, že ochorenie najviac zasahuje do emocionálneho prežívania rodičov, ich obáv z budúcnosti diețat’a. Rodičia uvádzali, že ochorenie najmenej zasiahlo do oblasti ich zamestnania, chodu domácnosti a najmenej ich trápi čas, ktorý venujú starostlivosti o diet’a $\mathrm{v}$ súvislosti s ochorením. Identifikovanie miery vplyvu ochorenia na život rodičov môže byt východiskom pre adekvátne naplánovanie edukácie detí a ich rodičov, ktorá by mala ovplyvnit' emocionálne zvládanie, zmenu postojov a konania v súvislosti s ochorením.

\section{Abstract}

The goal was to map the impact of asthma bronchiale on 
the quality of life for families with children with the disease. Through a questionnaire to measure the quality of life of families child with asthma, Pediatric Asthma Caregiver's Quality of Life Questionnare, the authors looked subjective perception of the impact of disease on the lives of parents of children with asthma and problem areas in life that most concerns parents. The sample consisted of 21 parents whose children have Recondition stay in the High Tatras. Based on analyzing the data found that the disease interferes with the most emotional experience of parents, their fear of the future child. Parents reported that the illness struck at least within their areas of employment, running the household and they suffer the least time to pay for childcare in the context of the disease. Identifying the extent the impact of disease on the lives of parents can be the basis for planning adequate education of children and their parents, which would affect the emotional management, change attitudes and actions in relation to the disease.

\section{Klúčové slová}

astma bronchiale, vplyv ochorenia, kvalita života

\section{Key words}

bronchiale asthma, influence of disease, quality of life

\section{Úvod}

Chronické ochorenia v detskom veku významne ovplyvñujú nielen kvalitu diețat’a s daným ochorením, ale aj kvalitu života jeho rodiny. Astma bronchiale patrí medzi časté a závažné chronické ochorenia $v$ detskom veku. Podla údajov Národného centra zdravotníckych informácií bolo na slovensku v roku 2005180 
162 astmatikov. V priemere prevalencia astmy na Slovensku predstavuje 3,34 \%. (Astma TOP región,2008)

Vplyv astmy bronchiale na kvalitu života rodičov detí s týmto ochorením bol sledovaný vo viacerých výskumoch (Reichenberg, Broberg, 2001, s. 45-50) v oblastiach - strach a obavy rodičov týkajúce sa vývoja ochorenia u diet’at’a a jeho liečby; neschopnost' rodičov zmiernit', resp. ovplyvnit' symptómy ochorenia; obavy rodičov týkajúce sa sociálnych vztahov, podpory zo strany školy a zdravotníckych pracovníkov. Prežívanie vyššie uvedených problémov u rodičov je do významnej miery ovplyvňované závažnostiou atakov ochorenia a taktiež prítomnostou d’alšej, predovšetkým alergickej symptomatológie.

\section{Ciel práce}

V našej práci sme sa zamerali na zmapovanie vplyvu ochorenia na život rodičov diet'at'a s astmou. Ďalej sme zistoovali subjektívne vnímanie vplyvu ochorenia na život rodičov diet’at’a s astmou a problémové oblasti $v$ živote, ktoré najviac znepokojujú rodičov.

\section{Súbor}

Prieskumu sa zúčastnilo 21 rodičov, ktorých deti absolvovali ozdravný pobyt $v$ čase od 1.7. do 18.7. 2005 v liečebnom dome Helios na Štrbskom Plese. Výber vzorky respondentov bol zámerný. Kritériami začleňujúcimi do výskumu boli: rodičia detí vo veku 7 - 18 rokov, u ktorých bola diagnostikovaná astma bronchiale, ochota spolupracovat' a podpísaný informovaný súhlas $s$ účast’ou na výskume. Vyčleňujúcim kritériom bolo odmietnutie rodičov zúčastnit sa prieskumu. Rodičom sme distribuovali dotaznik na zistenie vplyvu ochorenia na život rodín diet’ata s astmou, priamo prostredníctvom osobného 
kontaktu počas príjmu diet’at’a do zariadenia. Na realizáciu prieskumu v liečebnom dome Helios na Štrbskom Plese sme získali písomný súhlas zariadenia. (Tab 1)

Tab. 1 Charakteristika vzorky rodičov

\begin{tabular}{|l|l|}
\hline Rodičia detí & Počet (n) \\
\hline Dotazník vyplnila matka & 15 \\
\hline Dotazník vyplnil otec & 4 \\
\hline Vyplnili obaja rodičia spolu & 2 \\
\hline Spolu & 21 \\
\hline
\end{tabular}

\section{Metodika}

Ako prieskumnú metódu sme použili dotazník kvality života rodín dietata s astmou- Paediatric Asthma Caregiver's Quality of Life Questionnare (PACQLQ). PACQLQ predstavuje dotaznik zameraný na hodnotenie vplyvu ochorenia na život rodičov detí s astmou bronchiale. Bol vytvorený v Kanade autormi Juniper et al. (1996, 27-34). Položky dotazníka boli konštruované na základe rozhovorov so 100 rodičmi, detí vo veku 7 - 18 rokov, u ktorých bola diagnostikovaná astma bronchiale. PACQLQ obsahuje 11 otázok, ktoré sú rozdelené do dvoch subškál. Prvú subškálu tvorí 7 otázok, ktorými sme chceli zistit', ako často ochorenie dietaata zasahuje do života rodiny. V tejto subškále respondenti ohodnotili jednotlivé položky zakrúžkovaním čísla na stupnici od 1 po 5 (1-nikdy, 2-zriedkavo, 3-občas, 4-často, 5-vel’mi často). Druhá subškála tvorí štyri otázky, ktorými sme chceli zistit' problémové oblasti v živote, ktoré najviac znepokojujú, trápia rodičov astmatických detí. V tejto subškále respondenti ohodnotili jednotlivé položky zakrúžkovaním Čísla na stupnici od 1 po 7 (1-absolútne netrápi, 2-netrápi, 3-skôr netrápi ako trápi, 4-neviem, 5-skôr 
trápi ako netrápi, 6-trápi, 7-vel’mi ma trápi). Dotazník kvality života rodín sme vyhodnocovali a spracovali v programe Microsoft Excel. V tabullkách sú počty odpovedí uvedené absolútnou početnost’ou (n), smerodajnou odchýlkou - v tabulke d'alej ako (SD) a aritmetickým priemerom - v tabulke d'alej ako $\bar{x}$.

\section{Výsledky}

Výsledky nášho prieskumu zamerané na zistenie subjektívneho vnímania vplyvu ochorenia na život rodičov diețat’a s astmou ukazujú, že ochorenie najviac zasahuje do emocionálneho prežívania rodičov $(\bar{x}-3,047 ; \quad S D \pm 1,023)$. Rodičia uvádzali, že ochorenie najmenej zasiahlo do oblasti ich zamestnania a chodu domácnosti ( $\bar{X}-2,24 ;$ SD $\pm 0,830)$. Nasledovná tabulka (Tab. 2) znázorn̆uje poradie jednotlivých oblastí života rodiny, ktoré sú ovplyvnené ochorením diet’at’a. Oblasti uvádzame od najviac po najmenej frekventované (v tejto časti dotazníka bola použitá pät’stupňová frekvenčná škála). Poradie bolo vytvorené na základe hodnôt priemeru.

Tab. 2 oblasti ovplyvňované astmou

\begin{tabular}{|l|l|l|}
\hline $\begin{array}{l}\text { Oblasti ovplyvnené astmou podla frekvencie } \\
\text { výskytu }\end{array}$ & Priemer & SD \\
\hline $\begin{array}{l}\text { 1. Emocionálne prežívanie } \\
\text { (pocit bezmocnosti, strachu) v súvislosti } \\
\text { S priebehom záchvatu (kašel' a pod. ) }\end{array}$ & 3,047 & 1,023 \\
\hline $\begin{array}{l}\text { 2. Znepokojenie, rozrušenost' v súvislosti } \\
\text { S ochorením diet’at’a }\end{array}$ & 2,952 & 0,740 \\
\hline $\begin{array}{l}\text { 3. Zmena plánov rodiny vo vzṫahu k ochoreniu } \\
\text { diet'at’a }\end{array}$ & 2,809 & 0,813 \\
\hline 4. Prežívanie stresu, netrpezlivosti & 2,761 & 1,044 \\
\hline
\end{tabular}




\begin{tabular}{|l|l|l|}
\hline $\begin{array}{l}\text { Oblasti ovplyvnené astmou podla frekvencie } \\
\text { výskytu }\end{array}$ & Priemer & SD \\
\hline $\begin{array}{l}\text { 5. Nočné vstávanie, prebdená noc } \\
\text { zásah do rodinných vzt’ahov }\end{array}$ & 2,523 & 0,872 \\
\hline $\begin{array}{l}\text { 6. Ovplyvnenie zamestnania, chodu domácnosti, } \\
\text { zán }\end{array}$ & 2,238 & 0,830 \\
\hline
\end{tabular}

Ďalej sme zistili, že rodičov najviac trápi, znepokojuje budúcnost' ich diet’at’a $(\bar{x}-4,523, S D \pm 1,03)$. Rodičia uvádzali, že najmenej ich zat’ažuje čas (X̄-3, SD \pm 1,264), ktorý venujú starostlivosti o diet’a $v$ súvislosti $s$ ochorením. Nasledovná tabulka (Tab 3) schematicky znázorn̆uje poradie jednotlivých oblastí života rodiny, ktoré sú ovplyvnené ochorením diet’ata. Oblasti uvádzame od najviac znepokojujúcich po najmenej (v tejto časti dotazníka bola použitá sedemstupňová frekvenčná škála). Poradie bolo vytvorené na základe hodnôt priemeru.

Tab. 3 Oblasti v živote rodičov, ktoré ich znepokojujú.

\begin{tabular}{|l|l|l|}
\hline Zoradenie znepokojujúcich oblastí podla intenzity & Priemer & SD \\
\hline 1. Obavy spojené s budúcnostou diet'at’a & 4,523 & 1,03 \\
\hline 2. Lieky a ich vedlajšie účinky & 4 & 1,183 \\
\hline 3. Obmedzenia v denných aktivitách u diet’at'a & 3,380 & 1,499 \\
\hline 4. Čas venovaný diet’atú v súvislosti s astmou & 3 & 1,264 \\
\hline
\end{tabular}

\section{Diskusia}

Pri chronickom ochorení akým je astma bronchiale je dôležitá compliance diet’ata a jeho rodičov; významnú úlohu zohráva selfmanažment ochorenia a zvládanie akútnych atakov v domácich podmienkach. Optimálna kontrola astmy podla odporúčaní GINA (Global Initiative for Asthma) by mala zabezpečit' pocit zdravia a zlepšit kvalitu života astmatika. Kvalita života 
detí s daným ochorením je determinovaná frekvenciou výskytu denných a nočných symptómov, eradikáciou exacerbácií, bez obmedzenia normálnych životných aktivít. Steven (2002, 107117) pri vyhodnotení dotazníka PACQLQ, zistil, že rodičia boli obmedzení vo svojej vlastnej každodennej činnosti, aktivite vzhladom ku nedostatku financií, alebo dôsledkom únavy, narušeného spánku. V našom prieskume, sme nespozorovali vel’ký dopad únavy a nočného vstávania na kvalitu života rodičov. Výsledky našej pilotnej štúdie potvrdzujú, že bezmocnost' a strach pri dýchacích t’ažkostiach diet’at’a sú významnými problémami, ktoré ovplyvňujú kvalitu života rodičov detí s astmou. Prežívanie strachu a obáv môže do významnej miery ovplyvnit’ u rodičov napríklad zvládanie akútnych atakov ochorenia v domácich podmienkach. Z oblastí, ktoré najviac zat’ažujú rodičov, vystupujú do popredia obavy o budúcnost’ diet'at’a. Na druhej strane ochorenie v menšej miere zasahovalo do ich pracovného života a chodu domácnosti. Dalheim - Englund (2004, 386-395) naznačuje vo svojej štúdií, že pri dobrej kooperácii medzi rodičmi, nemalo ochorenie významný dopad na vzt’ahy $v$ rodine

Naše výsledky poukazujú na dôležitost psychosociálnej opory ako významnej súčasti edukácie rodičov detí trpiacich astmou bronchiale. Záṫažové oblasti zistené $v$ našej pilotnej štúdii môžu byṫ nápomocné pri tvorbe obsahu edukácie pre deti s týmto ochorením.

Pre diet'a a jeho rodinu by nemala edukácia znamenat' absorbovanie teoretických, prakticky t’ažko uskutočnitel’ných zásad, ale predovšetkým podporu a zvládanie emocionálnej zát’aže, sebestačnost̉ v denných aktivitách, realizáciu primeraných rozhodnutí v self-manažmente ochorenia. Edukácia zameraná na vedomosti, realizovaná bez prítomnosti rodiča nie 
je efektívna v oblastiach, ktoré by mali ovplyvnit’ emocionálne zvládanie, zmenu postojov a konania v súvislosti s ochorením. Naša práca mala charakter prierezovej pilotnej štúdie. Použitie dotazníka PACQLQ na väčšej vzorke respondentov by mohlo prispiet k záverom širšie aplikovatelných v klinickej praxi.

\section{Záver}

Kvalitu života rodičov detí s astmou bronchiale najviac ovplyvňuje prežívanie bezmocnosti a strachu pri dýchacích t’ažkostiach diet’at’a ako aj obáv o budúcnost' diețat’a. Výsledky poukazujú na dôležitost psychosociálnej opory zameranej na zvládanie symptómov ochorenia $v$ edukácii rodičov detí trpiacich astmou bronchiale.

\section{Zoznam bibliografických odkazov}

Astma TOP región - najlepšie a najhoršie miesto na slovensku pre život astmatikov [online]. 2009. [cit.2009-1-10]. Dostupné z WWW: http://WWW.astrazeneca.sk/projektyAZ/astma-TOP-region. British Guideline on the Managment of Asthma [online]. 2006. 13. Marec 2006, [cit. 2006-3-13]. Dostupné $z$ WWW: http:/ www.guideline on the managment asthma. sk.

DALHEIM-ENGLUND, A.C. et al. 2004. Having a child with asthma - quality of life for Swedish parents. Journal of Clinical Nursing. 2004, no. 13, p.386-395. ISSN 0962-1067.

Global strategy for astma managment and prevention [online]. 2008.[cit.2008-12-20]. Dostupné z WWW http://www.ginasthma.com/Committees.asp? $11=7 \& 12=2$. Juniper, E.F. et al. 1996. Children and Adult Perceptions of Childhood Asthma. Pediatrics. 1996, vol.5, p. 27-34. ISSN 0031 4005 . 
Reichenberg, K., Broberg, A.G. 2001. The Paediatric Asthma Caregiver's Quality of Life Questionnaire in Swedish parents. Acta Pædiatr. 2001, vol.90, p.45-50.ISSN 0803-5253.

Steven, R. et al. 2002. Influence of Sociodemographics on the Health-Related Quality of Life of Pediatric Patients with Asthma and Their Caregivers. Journal of Asthma. 2002, vol. 39, no.2,p.107-117.ISSN 0277-0903.

\section{Kontakt na autora}

Mgr. Alena Valancová

Ústav ošetrovatel'stva JLF UK Martin

Malá hora 5

SK-036 01 Martin

valancovaljfmed. uniba, sk 